\title{
KELAYAKAN MEDIA PEMBELAJARAN PREZI MENGGUNAKAN PENDEKATAN SAINTIFIK
}

\section{FEASIBILITY OF PREZI LEARNING MEDIA USING SCIENTIFIC APPROACH}

\author{
Diyah Ayu Setia Ningsih ${ }^{1}$, Happy Komikesari ${ }^{2}$ \\ ${ }^{1}$ MA Miftahul Ulum Gisting Tanggamus \\ ${ }^{2}$ Prodi Pendidikan Fisika Fakultas Tarbiyah dan Keguruan Universitas Islam Negeri Raden Intan Lampung \\ E-mail: diyaha85@gmail.com
}

Diterima: 17 Mei 2019. Disetujui: 13 Juni 2019. Dipublikasikan: 31 Juli 2019

\begin{abstract}
This research aims to know the feasibility of prezi-based learning media using scientific approach on the material of SMP / MTS caloric level. This research uses research and development method by using model from Borg \& Gall which is adapted from Sugiono development model. The data of this study were obtained from questionnaire responses of educators and learners, questionnaire validation of material experts and media experts. The type of data produced is qualitative data which is analyzed by guidance criteria of assessment category to determine product quality. Researchers produce a product in the form of prezi-based learning media using scientific approach on the material of SMP / MTs caloric level. Based on the assessment of material experts get the percentage of $84.13 \%$ with very decent category, the assessment of media experts get the percentage of $84.62 \%$ with very decent category while the response of the students of the three schools received an average percentage of $84.8 \%$ in very decent category . Based on the assessment by material experts, media experts, educators and students' responses, it can be concluded that prezi-based learning media using scientific approach on caloric materials of junior high school / MTs is suitable for learning media.
\end{abstract}

Keywords: learning media, prezi

Abstrak: Penelitian ini bertujuan untuk; Mengetahui kelayakan media pembelajaran berbasis prezimenggunakan pendekatan saintifik pada materi kalor tingkat SMP/MTs. Penelitian ini menggunakan metode penelitian dan pengembangan (Research and Development) dengan menggunakan model dari Borg \& Gall yang diadaptasi dari model pengembangan Sugiono. Data penelitian ini diperoleh dari angket respon pendidik dan peserta didik, angket validasi ahli materi dan ahli media. Jenis data yang dihasilkan adalah data kualitatif yang dianalisis dengan pedoman kriteria kategori penilaian untuk menentukan kualitas produk. Peneliti menghasilkan suatu produk berupa media pembelajaran berbasis prezi menggunakan pendekatan saintifik pada materi kalor tingkat SMP/MTs. Berdasarkan penilaian ahli materi mendapatkan persentase $84,13 \%$ dengan kategori sangat layak, penilaian ahli media mendapatkan persentase $84,62 \%$ dengan kategori sangat layaksedangkan respon peserta didik ketiga sekolah tersebut memperoleh nilai presentase rata-rata sebesar $84,8 \%$ dalam kategori sangat layak. Berdasarkan penilaian oleh ahli materi, ahli media, pendidik dan respon peserta didik maka dapat disimpulkan bahwa media pembelajaran berbasis prezi menggunakan pendekatan saintifik pada materi kalor tingkatSMP/MTs layak digunakan sebagai media pembelajaran.

(C) 2019 Unit Riset dan Publikasi Ilmiah FTK UIN Raden Intan Lampung

Kata Kunci: media Pembelajaran, prezi

\section{PENDAHULUAN}

Pendidikan juga merupakan suatu tolok ukur kualitas dalam kemajuan bangsa, karena suatu pendidikan dalam negara maju akan menghasilkan sumber daya manusia yang berkualitas. Pendidikan adalah usaha sadar dan terencana untuk mewujudkan suasana belajar dan proses pembelajaran agar peserta didik secara aktif 
mengembangkan potensi dirinya untuk memiliki kekuatan spiritual keagamaan, pengendalian diri, kepribadian, kecerdasan, akhlak mulia, serta keterampilan yang diperlukan dirinya, masyarakat, bangsadan negara (UU No. 20 Tahun 2003).

Perkembangan teknologi informasi saat ini telah membawa perubahan yang sangat besar dalam setiap aspek kehidupan manusia. Salah satunya ialah dalam bidang pendidikan (Saputra, Wirawan, \& Arthana, 2016). Menurut Mundilarto sebagian besar pendidik mata pelajaran fisika di Indonesia miskin kreativitas, wawasan, pengetahuan, serta kurangnya penyampaian dalam komunikasi. Hal ini menyebabkan adanya pandangan-pandangan yang sulit terhadap mata pelajaran fisika serta menyebabkan motivasi belajar fisika menjadi rendah. Salah satu alat bantu yang dapat digunakan oleh guru dalam pembelajaran ialah media pembelajaran.

Media atau bahan juga dapat di artikan sebagai perangkat lunak (software) berisi pesan atau informasi pendidikan yang biasanya disajikan dengan mempergunakan peralatan (Sadiman, 2011). Media juga sebagai semua bentuk perantara yang digunakan oleh manusia untuk menyampaikan atau menyebar ide, gagasan, atau pendapat sehingga ide, gagasan atau pendapat yang dikemukakan itu sampai kepada penerima yang dituju (Arsyad, 2014).

Media pembelajaran yang menarik akan membuat siswa lebih terangsang untuk memperhatikan materi yang disampaikan sehingga tujuan dari materi akan lebih mudah tersampaikan ke dalam diri peserta didik dan dapat membantu peserta didik dalam memahami materi pembelajaran. Penggunaan media pembelajaran dalam proses pembelajaran juga akan memberi kontribusi terhadap pengoptimalan pencapaian tujuan pembelajaran (Utari, Kurniawan, \& Fatmaryanti, 2014).
Salah satu materi pokok dalam mata pelajaran IPA pada tingkat SMP/MTs adalah materi kalor. Materi ini merupakan materi yang tanpa kita sadari selalu berhubungan dengan kehidupan seharihari kita. Berdasarkan hasil wawancara di tiga sekolah penggunaan media pembelajaran pada materi kalor guru hanya sebatas menggunakan media persentasi microsoft powerpoint saja .

Pembuatan presentasi menggunakan microsoft powerpoint belum berevolusi terlalu banyak dalam kurun 50 tahun belakangan sejak ditemukan slide dan presentasi multimedia berbasis program tersebut. Kini selain power point banyak bermunculan multimedia baru yang hadir untuk membantu seseorang dalam presentasi. Salah satunya adalah program aplikasi prezi.Prezi merupakan media alternatif yang dapat menampilkan sebuah ide ataupun gagasan dalam sebuah tampilan yang saling berkaitan dalam sebuah tampilan saling berkaitan dalam sebuah tampilan slide dengan slide lainya dengan mudah, hal ini sangat membantu para siswa agar bisa dengan mudah mengerti materi presentasi yang sedang ditampilkan (Rosadi, Raharjo, \& Budiono, 2013).

Oleh karena itu peneliti merasa perlu adanya "Pengembangan Media Pembelajaran Berbasis Prezi Menggunakan Pendekatan Saintifik Pada Materi Kalor Tingkat SMP/MTs”.

\section{METODE PENELITIAN}

Dalam penelitian ini peneliti menggunakan metode penelitian dan pengembangan (Research and Development). Metode penelitian dan pengembangan adalah metode penelitian yang digunakan untuk menghasilkan produk tertentu, dan menguji keefektifan produk tersebut (Sugiyono, 2015).

Borg \& Gall menjelaskan bahwa penelitian dan pengembangan dalam pendidikan adalah model pengembangan berbasis industri yang melalui beberapa 
tahapan dengan tujuan menghasilkan suatu produk pembelajaran yang memenuhi standarisasi tertentu, yaitu efektif, efisien dan berkualitas (Yuberti, 2014).

Dalam penelitian dan pengembangan model Borg \& Gall yang telah dimodifikasi oleh Sugiyono di butuhkan sepuluh langkah pengembangan untuk menghasilkan produk akhir yang siap untuk diterapkan dalam lembaga pendidikan. Tetapi, peneliti membatasi langkah-langkah penelitian pengembangan dari sepuluh langkah menjadi tujuh langkah di karenakan mengingat waktu yang tersedia dan kesempatan yang terbatas. Prosedur yang dilakukan peneliti yaitu : 1). Potensi dan Masalah, 2). Menggumpulkan data, 3). Desain Produk, 4). Validasi Desain, 5). Revisi Desain, 6). Uji Coba Produk, 7). Revisi Produk.

Data penelitian dikumpulkan dengan menggunakan lembar validasi ahli, lembar respon pendidik, lembar respon peserta didik serta analisa data menggunakan skala likert. Rumus untuk menghitung persentase sebagai berikut :

Ket :

$$
x_{i}=\frac{\sum S}{S_{\max }} \times 100 \%
$$

$$
\begin{aligned}
& \mathrm{S}_{\max }=\text { Skor maksimal } \\
& \sum S=\text { Jumlah skor } \\
& x_{i}=\text { Nilai kelayakan angket tiap } \\
& \quad \text { aspek (Sugiyono, 2015) }
\end{aligned}
$$

Angket respon terhadap penggunaan produk 5 pilihan sesuai dengan konten pertanyaan. Pengubahan hasil penilaian ahli media, ahli materi, pedidik dan respon peserta didik dari huruf menjadi skor dengan ketentuan pada tabel berikut:

Tabel 1. Aturan Pemberian Skor

\begin{tabular}{cc}
\hline Kategori & Skor \\
\hline SB (Sangat Baik) & 5 \\
B (Baik) & 4 \\
C (Cukup) & 3 \\
K (Kurang) & 2 \\
SK (Sangat Kurang) & 1 \\
\hline
\end{tabular}

Angket respon untuk mengetahui ketertarikan media pembelajaran fisika berupa buku saku berbasis android pada materi fluida statis, responden diberikan angket.Mengetahui nilai akhir menggunakan analisis rata-rata butir yang bersangkutan dalam angket yaitu dengan perhitungan nilai kelayakan angket tiap aspek dibagi dengan banyaknya pernyataan.

Hasil skor persentase yang diperoleh dari penelitian diinterpretasikan dalam kriteria tabel 2.

Tabel 2. Skala Kelayakan Media Pembelajaran

\begin{tabular}{cl}
\hline Presentase & \multicolumn{1}{c}{ Kriteria } \\
\hline $81 \%-100 \%$ & Sangat Layak \\
$61 \%-80 \%$ & Layak \\
$41 \%-60 \%$ & Cukup Layak \\
$21 \%-40 \%$ & Kurang Layak \\
$0 \%-20 \%$ & Sangat Kurang Layak \\
\hline
\end{tabular}

Tabel kriteria kelayakan analisis presentase digunakan sebagai acuan melihat persentase uji coba produk.dikategorikan sangat layak jika $\mathrm{X}$ $>81 \%$; layak jika $61 \%<\mathrm{X} \leq 80 \%$; Cukup jika $41 \%<\mathrm{X} \leq 60 \%$; Kurang jika $21 \%<X \leq 40 \%$ dan Sangat Kurang jika $X$ $\leq 20 \%$ (Asyhari \& Silvia, 2016)

\section{HASIL DAN PEMBAHASAN}

Hasil analisis kebutuhan evaluasi pembelajaran terhadap produk yang akan dikembangkan melalui wawancara tidak terstruktur terhadap guru IPA bahwa Berdasarkan pra penelitian yang telah dilakukan dapat disimpulkan bahwa masalahan yang terjadi sama yaitu kurangnya kreativitas guru dalam menggunakan media, dan kurangnya penerapan guru untuk melakukan pendekatan yang digunakan dalam proses pembelajaran.Potensi dalam penelitian dan pengembangan ini adalah masih kurangnya guru dalam menggunakan media dalam proses pembelajaran dan guru belum pernah menggunakan presentasi prezi dalam proses pembelajaran terutama pada materi kalor. Masalah dalam penelitian pengembangan ini adalah sedikitnya media pembelajaran dalam proses pembelajaran, guru hanya sebatas menggunakan media yaitu media 
power point saja..Berdasarkan hasil analisis diatas maka diperlukan media alternatif yang dapat memotivasi minat mereka dalam memahami materi IPA, Media alternatif yang dapat dikembangkan untuk peserta didik saat ini adalah media pembelajaran prezi.Karena Prezi dapat menggeser paradigma pembelajaran yang semula berpusat pada guru menjadi berpusat pada siswa dan guru hanya sebagai fasilitator sehingga siswa menjadi aktif belajar, tidak lagi mengandalkan guru sebagai narasumber tunggal.Harapannya dengan adanyamedia pembelajaranprezi dapat menjadi alternatif yang dapat memotivasi minat mereka dalam memahami materi IPA.

\section{a. Validasi Ahli Materi}

Hasil penilaian validasi ahli materi pada produk disajikan dalam tabel 3 sebagai berikut:

Tabel 3. Hasil Penilaian Validasi Ahli Materi

\begin{tabular}{ll}
\hline \multicolumn{1}{c}{ Aspek } & \multicolumn{1}{c}{ Persentase } \\
\hline Kualitas isi & $81,90 \%$ \\
Kebahasaan & $80 \%$ \\
Keterlaksanaan & $85,5 \%$ \\
Tampilan visual & $81,6 \%$ \\
Aspek Suara & $88,8 \%$ \\
Kemudahan Penggunaan & $87 \%$ \\
Rata-rata & $84,13 \% \%$ \\
\hline
\end{tabular}

Berdasarkan tabel 3 penilaian oleh validasi ahli materi diatas dapat diketahui Penilaiaan pada aspek 1 tentang kualitas isi dengan materi kalor rmendapatkan persentase kelayakan sebesar 81,90 \% dengan kategori sangat layak. Pada aspek 2 tentang kebahasaan mendapatkan persentase kelayakan sebesar $80 \%$ dengan kategori sangat layak. Pada aspek 3 tentang keterlaksanaan mendapatkan persentase kelayakan sebesar 85,5 \% dengan kategori sangat layak. Pada aspek 4 tampilan visual mendapatkan persentase $81,6 \%$ dengan kategori sangat layak. Pada aspek 5 aspek suara mendapatkan persentase $88,8 \%$ dengan kategori sangat layak . Pada aspek 6 kemudahan menggunakan media mendapatkan persentase $87 \%$ dengan kategori sangat layak . sehingga diperoleh rata-rata dari 6 aspek $84,13 \%$ yang berarti media pembelajaran ini dalam kategori sangat layak dari penilaian ahli materi.

\section{b. Validasi Ahli Media}

Hasil penilaian validasi ahli media pada produk disajikan dalam tabel 4 sebagai berikut:

Tabel 4. Hasil Penilaian Validasi Ahli Media

\begin{tabular}{ll}
\hline \multicolumn{1}{c}{ Aspek } & \multicolumn{1}{c}{ Persentase } \\
\hline Kualitas isi & $80 \%$ \\
Kebahasaan & $84,44 \%$ \\
Keterlaksanaan & $80 \%$ \\
Tampilan visual & $80 \%$ \\
Aspek Suara & $93,33 \%$ \\
Kemudahan Penggunaan & $90 \%$ \\
Rata-rata & $84,62 \% \%$ \\
\hline
\end{tabular}

Pada tabel tersebut merupakan hasil penilaian dari ketiga ahli media.penilaian ahli media.Penilaiaan pada aspek 1 tentang kualitas isi dengan materi kalor mendapatkan persentase kelayakan sebesar $80 \%$ dengan kategori sangat layak. Pada aspek 2 tentang kebahasaan mendapatkan persentase kelayakan sebesar $84,44 \%$ dengan kategori sangat layak. Pada aspek 3 tentang keterlaksanaan mendapatkan persentase kelayakan sebesar $80 \%$ dengan kategori sangat layak. Pada aspek 4 tampilan visual mendapatkan persentase $80 \%$ dengan kategori sangat layak . Pada aspek 5 aspek suara mendapatkan persentase 93,33\% dengan kategori sangat layak . Pada aspek 6 kemudahan menggunakan media mendapatkan persentase $90 \%$ dengan kategori sangat layak . sehingga diperoleh rata-rata dari 6 aspek 84,62\% yang berarti media pembelajaran ini dalam kategori sangat layak dari penilaian ahli media.

\section{c. Respon Peserta Didik}

Hasil penilaian responpeserta didik pada produk disajikan dalam tabel 5 sebagai berikut: 
Tabel 5. Hasil Penilaian Respon Peserta Didik

\begin{tabular}{lll}
\hline Aspek Penilaian & $\begin{array}{l}\boldsymbol{\Sigma} \text { Nilai Per } \\
\text { Aspek }\end{array}$ & $\begin{array}{l}\boldsymbol{\Sigma} \text { Rata- } \\
\text { Rata } \\
\text { Persentase } \\
\text { Kelayakan }\end{array}$ \\
\hline Kualitas Isi & 754,3 & $83,8 \%$ \\
Tampilan Media & 378 & $83,7 \%$ \\
Kualitas Tekhnis & 520,6 & $87 \%$ \\
Jumlah & 1652,9 & $254,5 \%$ \\
Rata-Rata & 550,9 & $84,8 \%$ \\
\hline
\end{tabular}

Dari tabel diatas menunjukan hasil rata-rata persentase tanggapan uji coba lapangan ditiga sekolah atau respon peserta didik.Berdasarkan hasil uji coba lapangan yang dilakukan di MTs Muhammadiyah Sukarame, SMP Negeri 1 Gisting dan SMP Negeri 2 Pugung dengan total 90 peserta didik diketahui hasil rata-rata tanggapan uji coba lapangan, pada aspek 1 tentang kualitas isi mendapatkan jumlah nilai per aspek sebesar 754,3 dan rata-rata persentase kelayakan 83,8\%. Pada aspek 2 penilaian tentang aspek tampilan media mendapatkan jumlah nilai per aspek sebesar 378 dan rata-rata persentase kelayakan 83,7\%. Pada aspek 3 penilaian tentang kualitas tekhnis mendapatkan jumlah nilai per aspek sebesar 520,6 dan persentase kelayakan $87 \%$. Sedangkan jumlah rata-rata seluruh aspek sebesar 1652,9 dengan rata-rata persentase kelayakan sebesar $254,5 \%$, dan rata-rata nilai per aspek sebesar 550,9 dengan persentase kelayakan sebesar 84,8\%. Dengan kategori sangat "sangat layak".

\section{d. Respon Pendidik Ditiga Sekolah}

Hasil penilaian respon pendidik ditiga sekolah pada produk disajikan dalam tabel 6 sebagai berikut:

Tabel 6. Hasil Penilaian Respon Pendidik Ditiga Sekolah

\begin{tabular}{lr}
\hline Aspek Penilaian & \multicolumn{2}{c}{ Persentase } \\
\hline Kualitas Isi & $91,11 \%$ \\
Tampilan Media & $85 \%$ \\
Kualitas Tehnis & $82,22 \%$ \\
Rata-rata & $86,11 \%$ \\
\hline
\end{tabular}

Dari tabel diatas menunjukan hasil ratarata persentase tanggapan pendidik dari ketiga sekolah.Penilaian aspek 1 kualitas isi mendapat persentase kelayakan 91,11\% dengan kategori sangat layak. Penilaian aspek 2 tampilan media mendapatkan persentase kelayakan $85 \%$ dengan kategori sangat layak. Penilaian aspek 3 kualitas tekhnis mendapat persentase kelayakan sebesar 82,22\% dengan kategori“sangat layak'. Berdasarkan tahap-tahap yang dilakukan dalam penelitian ini, media pembelajaran ini mempunyai kualitas yang sangat baik dan layak digunakan untuk peserta didik kelas VIISMP/MTs.

\section{KESIMPULAN}

Pengembangan media pembelajaran berbasis prezi menggunakan pendekatan saintifik pada materi kalor tingkat SMP/MTs layak digunakan dalam pembelajaran. Kelayakan produk berdasarkan penilaian ahli materi dan ahli media dengan penilaian persentase ratarata $84,13 \%$ dalam kategori sangat layak dan $84,62 \%$ dalam kategori sangat layak. Hasil uji coba yang dilakukan yaitu uji coba kelompok kecil dengan persentase kelayakan rata-rata sebesar $83,2 \%$ dalam kategori sangat layak. Pada uji coba lapangan yang dilakukan di tiga sekolah mendapatkan persentase kelayakan sebesar $84,8 \%$ dalam kategori sangat layak.

\section{DAFTAR PUSTAKA}

Arsyad, A. (2014). Arsyad, Azhar. Media Pembelajaran. Jakarta: Rajawali Pers.

Asyhari, A., \& Silvia, H. (2016). Pengembangan Media Pembelajaran Berupa Buletin dalam Bentuk Buku Saku untuk Pembelajaran IPA Terpadu. Jurnal Ilmiah Pendidikan Fisika Al-Biruni, 5(April), 1-13. https://doi.org/10.24042/jpifalbiruni. v5i1.100

Rosadi, H., Raharjo, \& Budiono, D. (2013). Kelayakan Teoritis Media Slide Prezi pada Materi Sistem 
Peredaran Darah Manusia. BioEdu Berkala Ilmiah Pendidikan Biologi, 2(3), 306-309.

Sadiman, A. (2011). Media Pendidikan Pengertian, Pengembangan, dan Pemanfaatannya. Jakarta: Rajawai Pers.

Saputra, P. M. A., Wirawan, I. M. A., \& Arthana, I. K. R. (2016). Film Animasi Pembelajaran Sistem Pencernaan Manusia pada Kelas VIII SMP Negeri 3 Banjar Tahun Ajaran 2015 / 2016. Kumpulan Artikel Mahasiswa Pendidikan Teknik Informatika (KARMAPATI), 5(2).

Sugiyono. (2015). Metode Penelitian Pendidikan Pendekatan Kuantitatif, Kualitatif, dan R\&D. Bandung: Alfabeta.

Utari, Y. P., Kurniawan, E. S., \& Fatmaryanti, S. D. (2014). Pengembangan Media Pembelajaran Fisika Online Prezi dalam Pokok Bahasan Alat Optik pada Siswa Kelas X IPA SMA Negeri 3 Purworejo Tahun Pelajaran 2013 / 2014. Radiasi, 5(2), 45-49.

Yuberti. (2014). Penelitian dan Pengembangan yang Belum Diminati dan Perspektifnya. Jurnal Ilmiah Pendidikan Fisika 'Al-Biruni, 3(2), 1-15. 